\title{
FAKTOR PENENTU PILIHAN KONSUMEN KOMODITI PERTANIAN TERHADAP TEMPAT BERBELANJA DI PASAR TRADISIONAL DAN PASAR MODERN DI KOTA MANADO
}

\author{
Zely Ela Karouw \\ O. Esry H. Laoh \\ Juliana R. Mandei
}

\begin{abstract}
This study aims to describe the factors which determine consumer decisions of agricultural commodities to shop at traditional markets and modern markets in the city of Manado. This study took place in June 2015 until July 2015 at Traditional and Modern Market Market in the city of Manado. In this study, the data used is primary data obtained from questionnaires and secondary data obtained from the relevant agencies, namely the Manado Statistics Central Agency (BPS) and Department of Industry and Trade of Manado. Variables measured were age, education level, income, location, product, price, atmosphere in the outlets, service, comfort, prestige. Analysis of the data used is the logistic regression model analysis. The results showed that there are two variables that significantly determine the consumer's decision of choosing to shop in agricultural commodities at Traditional Market or Modern Market in the city of Manado is the atmosphere in the stores and services. Consumer's who want a high atmospheric in the stores, preferring to go shopping to the modern market, while consumer's who want good services, prefer to shop in tradisional market.
\end{abstract}

Keywords:the determinant factors, consumer decisions, agriculture, market, Manado City

\begin{abstract}
ABSTRAK
Penelitian ini bertujuan untuk mendeskripsikan faktor-faktor yang menentukan keputusan konsumen komoditi pertanian untuk berbelanja di pasar tradisional dan pasar modern di Kota Manado. Penelitian ini berlangsung pada bulan Juni 2015 sampai dengan Juli 2015 di Pasar Tradisional dan Pasar Modern di Kota Manado. Pada penelitian ini data yang digunakan adalah data primer yang diperoleh dari kuisioner dan data sekunder yang diperoleh dari instansi yang terkait yaitu Badan Pusat Statistik (BPS) Kota Manado dan Dinas Perindustrian Perdagangan Kota Manado.Variable yang diukur adalah umur, tingkat pendidikan, penghasilan, lokasi, produk, harga, atmosfer dalam gerai, pelayanan, kenyamanan, gengsi. Analisis data yang digunakan adalah analisis model regresi logistic.Hasil penelitian menunjukkan bahwa terdapat 2 variabel yang signifikan menentukan keputusan konsumen komoditi pertanian memilih tempat berbelanja di Pasar Tradisional atau Pasar Modern di kota Manado yaitu atmosfir dalam gerai dan pelayanan. Konsumen yang menginginkan atmosfer gerai yang tinggi, lebih memilih pergi berbelanja ke pasar modern, sedangkan konsumen yang menginginkan pelayanan yang baik, lebih memilih berbelanja ke pasar tradisional.
\end{abstract}

Kata Kunci: faktor penentu, keputusan konsumen, pertanian, pasar, Kota Manado 


\section{PENDAHULUAN}

\section{Latar Belakang}

Bisnis eceran merupakan bagian dari saluran distribusi yang memegang peranan penting dalam rangkaian pemasaran dan merupakan penghubung atau perantaraantara konsumen dan produsen.Bisnis ritel atau usaha eceran di Indonesia telah mengalami kemajuan pesat pada beberapa tahun terakhir. Hal ini dapat dilihat dari banyaknya toko, kantor, pabrik, jenis usaha lainnya. Kebanyakan dari usaha ini diambil alih oleh swasta.Pemerintah juga memiliki usaha-usaha di bidang perkantoran, pertokoan dan lainnya.Kemajuan bisnis eceran yang ada di Indonesia diakibatkan karena adanya perkembangan usaha manufaktur serta peluang pasar yang cukup terbuka yang disebabkan oleh adanya dampak dari lajunya kondisi ekonomi masyarakat.Perkembangan ini mengakibatkan perubahan yang mempengaruhi kehidupan masyarakat, terutama yang ada di kota-kota besar, dimana salah satu perubahan itu adalah tempat belanja masyarakat (Pangestu, 2007 dalam Purba, 2009).

Salah satu media dalam kegiatan ritel adalah pasar.Pasar adalah media pertemuan antara pembeli dan penjual lebih dari satu yang melakukan transaksi. Bagi konsumen, adanya pasar akan mempermudah memperoleh barang dan jasa kebutuhan sehari-hari. Adapun bagi produsen, pasar menjadi tempat untuk mempermudah proses penyaluran barang hasil produksi. Berdasarkan jenis dan cara penawarannya, pasar dapat dibedakan menjadi dua yaitu pasar tradisional dan pasar modern (Jendi, 2013). Pasar begitu akrab dengan kehidupan masyarakat, baik di kota maupun di desa. Di pasar kita bisa berbelanja sayuran, daging, sembilan kebutuhan pokok, bumbu dapur, buah-buahan, dsb (Malano, 2011).Produk yang ditawarkan oleh pemasar berupa kebutuhan sehari-hari termasuk pangan.Pangan merupakan sumber energi dan makanan bagi manusia.Seluruh pangan tersebut secara langsung maupun tidak langsung berasal dari tanaman yang merupakan komoditi pertanian.Berbagai komoditi pertanian seperti sayuran dan buah-buahan dapat memenuhi kebutuhan manusia.
Dahulu pasar tradisional merupakan tempat utama yang dituju oleh konsumen untuk berbelanja. Tetapi karena adanya perkembangan dari waktu ke waktu banyak bermunculan pasar-pasar modern atau swalayan atau dikenal dengan nama supermarket (Pangestu, 2007 dalam Purba, 2009).

Kehadiran pasar modern (Hypermarket, Supermarket, Minimarket) pada sekitar awal 1980-an pada awalnya tidak mengancam pasar tradisional. Kehadiran para pasar modern yang menyasar konsumen menengah ke atas, saat itu lebih menjadi alternatif dari pasar tradisional yang identik dengan kondisi pasar yang kumuh, dengan tampilan dan kualitas yang buruk, serta harga jual rendah serta sistem tawar menawar konvensional.Namun sekarang ini kondisinya sudah banyak berubah. Hypermarket dan Supermarket banyak bermunculan di manamana.Kondisi ini muncul sebagai konsekuensi dari berbagai perubahan di masyarakat.Sebagai konsumen, masyarakat menuntut hal yang berbeda di dalam aktivitas belanja.Kondisi ini ditambah dengan semakin meningkatnya tingkat pengetahuan, pendapatan, dan jumlah pendapatan keluarga ganda (suami-istri bekerja) dan dengan waktu yang terbatas.Konsumen menuntut pasar untuk memberikan "nilai lebih" dari setiap uang yang dibelanjakannya.Pasar harus mampu mengakomodasi tuntutan tersebut jika tidak ingin ditinggal pelanggannya. Memang tidak bisa dipungkiri bahwa keberadaan pasar modern dewasa ini menjadi tuntutan dan konsekuensi dari gaya hidup yang berkembang di masyarakat kita. Tidak hanya di kota metropolitan tapi sudah merambah di kota kecil di tanah air. Sangat mudah menjumpai Minimarket, Supermarket, Hypermarket di sekitar tempat tinggal kita.Tempat-tempat tersebut menjanjikan tempat yang nyaman dengan harga yang tidak kalah menariknya.Namun dibalik kesenangan tersebut ternyata membuat pasar kelas menengah dan bawah mengeluh (Fadhilah, 2011).

Meskipun demikian, pasar tradisional tetap memiliki keunggulan bersaing alamiah yang tidak dimiliki secara langsung oleh pasar modern.Lokasi yang strategis, area penjualan yang luas, keragaman barang yang lengkap, harga yang rendah, sistem tawar menawar yang menunjukkan keakraban antara penjual dan 
pembeli merupakan keunggulan yang dimiliki oleh pasar tradisional.Selain memiliki keunggulan alamiah, pasar tradisional memiliki berbagai kelemahan yang telah menjadi karakteristik dasar yang sangat sulit diubah. Faktor desain dan tampilan pasar, atmosfir, tata ruang, tata letak, keragaman dan kualitas barang, promosi penjualan, jam operasional pasar yang terbatas, serta optimalisasi pemanfaatan ruang jual merupakan kelemahan terbesar pasar tradisional dalam menghadapi persaingan dengan pasar modern.

Ketika konsumen menuntut "nilai lebih " atas setiap uang yang dibelanjakannya, maka kondisi pasar tradisional yang kumuh, kotor, bau dengan atmosfir seadanya dalam jam operasional yang relatif terbatas tidak mampu mengakomodasi hal ini. Kondisi ini menjadi salah satu alasan konsumen untuk beralih dari pasar tradisional ke pasar modern. Artinya, dengan nilai uang yang relatif sama, pasar modern memberikan kenyamanan, keamanan dan keleluasaan berbelanja yang tidak dapat diberikan pasar tradisional.

Perilaku konsumen merupakan tindakan suatu individu dalam membuat keputusan dalam membelanjakan sumberdaya yang dimilikinya untuk memperoleh atau untuk mendapatkan barang dan jasa yang akan dikonsumsi nantinya (Purba, 2009). Adapun faktor yang mempengaruhi perilaku masyarakat sebagai konsumen terdiri dari faktor sosial, faktor ekonomi dan faktor psikologis.

Banyaknya faktor yang mempengaruhi masyarakat menyebabkan perbedaan pola perilaku konsumen dalam menentukan preferensi belanjanya.Kajian/study tentang faktor penentu pilihan konsumen ini dapat dilihat melalui indikator frekuensi kunjungan berbelanja ke pasar baik pasar tradisional maupun modern.Kota Manado kini menjadi salah satu sasaran empuk bagi para pebisnis lokal maupun asing, terbukti kini telah banyaknya pasar modern yang kini menjamur dimana-mana. Perkembangan minimarket di kota Manado seakan seperti jamur yang tumbuh dimusim penghujan. Tempat belanja bagi konsumen komoditi pertanianpun semakin banyak selain pasar tradisional. Kondisi tersebut lambat laun akan menjatuhkan pasar tradisional yang di dalamnya didominasi masyarakat kecil.

Berdasarkan uraian di atas maka penulis memilih dan tertarik untuk mengangkat masalah mengenai "Faktor penentu pilihan konsumen terhadap tempat berbelanja di pasar tradisional dan pasar modern di Kota Manado”.

\section{Rumusan Masalah}

Faktor-faktor apa saja yang menentukan keputusan konsumen komoditi pertanian untuk berbelanja di pasar tradisional dan pasar modern di Kota Manado.

Tujuan Penelitian

Penelitian ini bertujuan, mendeskripsikan faktor-faktor yang menentukan keputusan konsumen komoditi pertanian untuk berbelanja di pasar tradisional dan pasar modern di Kota Manado.

\section{Manfaat Penelitian}

Manfaat dari penelitian ini adalah:

1. Bagi Pemerintah kota Manado, PD Pasar, dan Deperindag, sebagai masukan yang dapat dijadikan acuan untuk terus dapat memperhatikanfaktor-faktor yang mempengaruhi keputusan pembelian di Pasar Tradisional dan Pasar Modern sehingga dapat mengembangkan keberadaan pasar tradisional di kota Manado.

2. Bagi peneliti, sebagai bahan acuan untuk penelitian selanjutnya yang sesuai dengan topik penelitianini.

\section{METODOLOGI PENELITIAN}

\section{Waktu dan Tempat}

Lokasi penelitian ditentukan secara sengaja (purposive) di pasar tradisional (Pasar Pinasungkulan) dan pasar modern (Freshmart Swalayan) di Kota Manado.Penelitian ini berlangsung pada bulan Juni sampai dengan Juli 2015.

\section{Metode Pengumpulan Data}

Data yang dikumpulkan dalam penelitian ini terdiri dari data primer dan data sekunder. Data primer diperoleh dari wawancara langsung 
kepada responden dengan menggunakan daftar pertanyaan (kuesioner), sedangkan data sekunder diperoleh dari Badan Pusat Statistika Kota Manado, Dinas Perindustrian dan Perdagangan kota Manado.

\section{Metode Penarikan Sampel Konsumen}

Penarikan sampel konsumen dilakukan dengan metode accidental sampling, yakni siapa saja yang kebetulan ditemui pada saat berbelanja, dengan jumlah sebanyak 60 orang yang berusia antara 20 tahun sampai 65 tahun..

\section{Pengukuran Variabel}

Variabel dalam penelitian ini dibedakan menjadi dua yaitu variabel dependen dan variabel independen. Variabel dependen yang digunakan dalam penelitian ini adalah: Peluang berbelanja di pasar tradisional atau pasar modern sedangkan variabel independen yang digunakan dalam penelitian ini adalah: tingkat umur, tingkat pendidikan, tingkat penghasilan, lokasi, produk, harga, atmosfer dalam gerai, pelayanan, kenyamanan dan gengsi. Variabel yang diukur meliputi:

1. Tingkat umur konsumen adalah usia konsumen pada saat penelitian dilakukan yaitu umur 20 - 65 tahun.

2. Tingkat pendidikan konsumen adalah pendidikan formal terakhir yang pernah ditempuh oleh konsumen parameternya SD, SMP, SMA, Diploma, dan Sarjana. Variabel ini diukur dengan menggunakan skor, seperti SD (1), SMP (2), SMA (3), Diploma (4) dan Sarjana (5).

3. Tingkat penghasilan adalah pendapatan kotor yang diterima oleh konsumen setiap bulannya.

4. Lokasi adalah jauh dekatnya lokasi pasar dengan tempat tinggal konsumen.

5. Produk adalah kualitas dan kelengkapan produk komoditi pertanian di pasar.

6. Harga adalah harga produk komoditi pertanian di pasar.

7. Atmosfer dalam gerai adalah suasana di pasar dan penataan ruangan atau produk.

8. Pelayanan adalah pelayanan yang diberikan pedagang atau pramuniaga di pasar kepada konsumen.
9. Kenyamanan adalah rasa aman dan nyaman yang dirasakan oleh konsumen ketika berbelanja.

10. Gengsi adalah suatu keadaan dimana konsumen merasa mempunyai kebanggaan tersendiri dalam menggunakan produk atau berbelanja di suatu pasar tertentu.

11. Peluang konsumen memilih tempat berbelanja. Peluang diukur dengan menggunakan proporsi frekuensi berbelanja di pasar tradisional terhadap total frekuensi berbelanja dalam selang waktu 1 bulan.

\section{Metode Analisis Data}

Metode analisis data yang digunakan pada penelitian ini yaitu dengan menggunakan analisis regresi dengan model logit. Alat bantu yang digunakan untuk melakukan regresi adalah software MiniTab.

Dengan mempertimbangkan variabel tak bebas dalam penelitian ini yang dihadapkan pada dua pilihan (binary choice), maka terdapat beberapa teknik analisa untuk memecahkan masalah-masalah seperti ini, seperti analisis diskriminan, analisis peluang linear dan analisa peluang logistik.Dalam penelitian ini, analisis diskriminan tidak dapat digunakan, karena tidak dapat mengestimasi peluang kejadian. Analisis peluang linier juga tidak dapat dipilih, karena mengandung kelemahan formal, yaitu tidak mengandung kendala bagi nilai estimasi untuk berada dalam kisaran 0 sampai 1 yang menyebabkan residualnya bisa lebih kecil 0 maupun lebih besar 1. Model logistik adalah model yang cocok untuk dipakai dalam penelitian ini, mengingat variabel tak bebasnya bersifat binary choice (0 dan 1 ).

Model Regresi Logistik, sebagaimana fungsi regresi lainnya, digunakan juga untuk menggambarkan hubungan antara variabel tak bebas dengan satu atau lebih variabel bebas (Neter, Wasserman, Kutner, 1989 dalam Rengkung, 1997). Dengan demikian dapat dikatakan bahwa model ini akan dapat memprediksi probabilitas suatu kejadian atau situasi dengan syarat atau kondisi adanya variabel-variabel tertentu. Probabilitas disini merupakan suatu conditional probability (Sritua, 1993 dalam Rengkung, 1997). 
Model logit didasarkan pada fungsi peluang logistik kumulatif yang dispesifikasikan, sebagai berikut :

$$
\begin{array}{r}
P_{i}=F\left(\beta_{0}+\beta_{1} X_{1 i}\right)=\frac{1}{1+e^{-Z_{i}}} \\
=\frac{1}{1+e^{-\left(\beta_{0}+\beta_{1} X_{1 i}\right)}}
\end{array}
$$

Dalam fungsi diatas, $F$ merupakan frekuensi, e merupakan bilangan dasar logaritma natural (ln) yang diperkirakan sama dengan 2.71828128 atau dibulatkan menjadi 2.71828. $\mathrm{P}_{\mathrm{i}}$ merupakan peluang bahwa suatu obyek pengamatan akan tergolong ke dalam kategori tertentu berdasarkan nilai tertentu dari variabel bebas $\mathrm{X}_{1}$.

Persamaan diatas dapat juga dinyatakan dalam bentuk linear logaritmik, sebagai berikut:

$\mathrm{Z}_{\mathrm{i}}=\ln \left(\frac{\mathrm{P}_{\mathrm{i}}}{1-\mathrm{P}_{\mathrm{i}}}\right)$ atau,

$\ln \left(\frac{\mathrm{P}_{\mathrm{i}}}{1-\mathrm{P}_{\mathrm{i}}}\right)=\mathrm{Z}_{\mathrm{i}}=\beta_{0}+\beta_{1} \mathrm{X}_{1 \mathrm{i}}+\beta_{2} \mathrm{X}_{2 \mathrm{i}}+$ $\beta_{3} X_{3 i}+\beta_{4} X_{4 i}+\beta_{5} X_{5 i}+\beta_{6} X_{6 i}+\beta_{7} X_{7 i}$

Keterangan :

$\ln \quad=$ Probabilitas

$\mathrm{Z}_{\mathrm{i}}=\beta_{0}+\beta_{1} \mathrm{X}_{1 \mathrm{i}}+\beta_{2} \mathrm{X}_{2 \mathrm{i}}+\beta_{3} \mathrm{X}_{3 \mathrm{i}}+$ $\beta_{4} \mathrm{X}_{4 \mathrm{i}}+\beta_{5} \mathrm{X}_{5 \mathrm{i}}+\beta_{6} \mathrm{X}_{6 \mathrm{i}}+\beta_{7} \mathrm{X}_{7 \mathrm{i}}$

$\mathrm{P}_{\mathrm{i}} \quad=$ Peluang berbelanja di pasar tradisional atau modern

$\mathrm{X}_{1}=$ Tingkat umur konsumen (Tahun)

$\mathrm{X}_{2} \quad=$ Tingkat pendidikan konsumen

(Tahun)

$\mathrm{X}_{3} \quad=$ Tingkat penghasilan (Rupiah)

$\mathrm{X}_{4}=$ Lokasi

$\mathrm{X}_{5}=$ Produk

$\mathrm{X}_{6}=$ Harga

$\mathrm{X}_{7} \quad=$ Atmosfir dalam gerai

$\mathrm{X}_{8} \quad=$ Pelayanan

$\mathrm{X}_{9} \quad=$ Kenyamanan

$\mathrm{X}_{10}=$ Gengsi

$\beta_{0} \quad=$ Konstanta

$\beta_{1}, \beta_{2}, \beta_{3}, \beta_{4}, \beta_{5}, \beta_{6}, \beta_{7}=$ Parameter dugaan

Untuk menduga persamaan diatas secara langsung adalah tidak mungkin, karena $P_{i}$ hanya mengambil nilai 0 dan 1 , dimana komponen $\left(\frac{\mathrm{P}_{\mathrm{i}}}{1-\mathrm{P}_{\mathrm{i}}}\right)$ akan menjadi 0 bila $\mathrm{P}_{\mathrm{i}}=0$ dan menjadi tidak terdefinisi apabila $P_{i}=1$.

Untuk menghindari $P_{i}=0$ dan $P_{i}=1$, maka harus menggunakan periode waktu atau jangka waktu seperti dalam penelitian ini harus mengetahui misalnya dalam jangka waktu 1 bulan terakhir berapa kali konsumen pergi berbelanja di pasar tradisional dan pasar modern. Dengan demikian model logit dapat diduga berdasarkan nilai-nilai peluang tertentu dari setiap data pengamatan. Jika kita didefinisikan $r_{i}$ sebagai frekuensi berbelanja di pasar tradisional dapat diduga melalui:

Keterangan :

$$
\widehat{\mathrm{P}}_{1}=\frac{\mathrm{r}_{\mathrm{i}}}{\mathrm{n}_{\mathrm{i}}}
$$

$\widehat{\mathrm{P}}_{1} \quad=$ Peluang konsumen komoditi pertanian memilih tempat berbelanja ke pasar tradisional.

$\mathrm{r}_{\mathrm{i}} \quad=$ Frekuensi konsumen berbelanja ke pasar tradisional.

$\mathrm{n}_{\mathrm{i}} \quad=$ Total frekuensi berbelanja dalam 1 bulan

\section{Hipotesis}

$\mathrm{H}_{0}$ :tingkat umur, tingkat pendidikan, tingkat penghasilan, jumlah tanggungan, lokasi, produk, harga, atmosfir dalam gerai, pelayanan, kenyamanan, dan gengsi tidak menentukan konsumen komoditi pertanian memilih tempat berbelanja.

$\mathrm{H}_{1}$ :tingkat umur, tingkat pendidikan, tingkat penghasilan, jumlah tanggungan, lokasi, produk, harga, atmosfir dalam gerai, pelayanan, kenyamanan, dan gengsi menentukan konsumen komoditi pertanian memilih tempat berbelanja.

\section{HASIL DAN PEMBAHASAN}

\section{Deskripsi Umum Wilayah Penelitian}

Kota Manado terletak di antara $1^{\circ} 30^{\prime}$ $1\left[^{\mathrm{B} 1}\right]^{\circ} 40^{\prime}$ Lintang Utara, dan $124^{\circ} 40^{\prime}$ $126[\mathrm{~B} 2]^{\circ}$ 50' Bujur Timur. Kota Manado berbatasan dengan : Sebelah Utara dengan Kabupaten Minahasa Utara, Sebelah Timur dengan Kabupaten Minahasa Utara, dan 
Kabupaten Minahasa, Sebelah Selatan dengan Kabupaten Minahasa, Sebelah Barat dengan Laut Sulawesi.

Tabel 1. Luas Kota Manado menurut Kecamatan

\begin{tabular}{|c|c|c|}
\hline Kecamatan & Luas $\left(\mathrm{Km}^{2}\right)$ & $\%$ \\
\hline$(1)$ & (2) & (3) \\
\hline Malalayang & 17,12 & 10,9 \\
\hline Sario & 1,75 & 1,1 \\
\hline Wanea & 7,85 & 5,0 \\
\hline Wenang & 3,64 & 2,3 \\
\hline Tikala & 7,10 & 4,5 \\
\hline Paal Dua & 8,02 & 5,1 \\
\hline Mapanget & 49,75 & 31,6 \\
\hline Singkil & 4,68 & 3,0 \\
\hline Tuminting & 4,31 & 2,7 \\
\hline Bunaken & 36,19 & 23,0 \\
\hline Bunaken Kepulauan & 16,85 & 10,7 \\
\hline Manado & 157,26 & 100 \\
\hline
\end{tabular}

Sumber : Manado dalam angka, 2014

Tabel 1 menunjukkan bahwa secara administratif Kota Manado terbagi ke dalam 11 wilayah kecamatan dan 87 kelurahan/desa. Kota Manado memiliki luas wilayah sebesar 157,26 $\mathrm{km} 2$.

Kota Manado memiliki topograpi tanah yang bervariasi untuk tiap kecamatan. Secara keseluruhan, Kota Manado memiliki keadaan tanah yang berombak sebesar 37,95 persen dan dataran landai sebesar 40,16 persen dari luas wilayah. Sisanya dalam keadaan tanah berombak berbukit dan bergunung.Ketinggian dari permukaan laut pada tiap-tiap kecamatan di Kota Manado bervariasi. Secara keseluruhan, sebesar 92,15 persen dari luas wilayah Kota Manado terletak pada ketinggian 0-240 dari permukaan laut. Hal ini disebabkan tekstur alam Kota Manado yang berbatasan dengan pantai dan dengan kontur tanah yang berombak dan berbukit.Sebagai daerah yang terletak di garis khatulistiwa, maka Kota Manado hanya mengenal dua musim yaitu musim hujan dan kemarau. Curah hujan di suatu tempat antara lain ditentukan oleh keadaan iklim, keadaan orographi dan perputaran/pertemuan arus udara. Oleh karena itu jumlah curah hujan bervariasi menurut bulan. Berdasarkan pengamatan di Stasiun Meteorologi Manado, rata-rata curah hujan selama tahun 2013 berkisar antara $78 \mathrm{~mm}$ (bulan Maret) sampai $567 \mathrm{~mm}$ (bulan Februari). Suhu udara di suatu tempat antara lain ditentukan oleh tinggi rendahnya tempat tersebut terhadap permukaan laut dan jaraknya dari pantai. Pada tahun 2013, suhu udara ratarata pada siang hari berkisar antara $30,00 \mathrm{C}$ sampai 32,50C, sedangkan suhu udara pada malam hari berkisar antara 22,10C sampai 23,40C.Suhu udara maksimum terdapat pada bulan Juni dan September, sedangkan suhu udara minimum terdapat pada bulan September.Kota Manado mempunyai kelembaban udara relatif tinggi dengan rata-rata berkisar antara 76 - 88 persen. Keadaan angin di Kota Manado pada tahun 2013 rata-rata berkisar antara 2,1-4,5 knots.

\section{Kependudukan}

Berdasarkan data Badan Pusat Statistika Kota Manado tahun 2014, jumlah penduduk Kota Manado berjumlah 419.596 jiwa dengan 111.266 rumah tangga yang tersebar di setiap kecamatan di Kota Manado.

Tabel 2. JumlahPenduduk Kota Manado Menurut Kelompok Umur dan Jenis Kelamin

\begin{tabular}{|c|c|c|c|c|c|c|}
\hline \multirow{2}{*}{$\begin{array}{c}\text { Golong- } \\
\text { an } \\
\text { Umur }\end{array}$} & \multicolumn{2}{|c|}{ Laki-laki } & \multicolumn{2}{|c|}{ Perempuan } & \multicolumn{2}{|c|}{ Jumlah } \\
\hline & Jiwa & $\begin{array}{c}\text { Persen } \\
\%\end{array}$ & $\begin{array}{l}\text { Jiwa } \\
\end{array}$ & $\begin{array}{c}\text { Persen } \\
\% \\
\end{array}$ & Jiwa & $\begin{array}{c}\text { Persen } \\
\% \\
\end{array}$ \\
\hline (1) & (2) & (3) & (4) & $(5)$ & (6) & $(7)$ \\
\hline $0-4$ & 17.869 & 8,48 & 17.185 & 8,23 & 35.054 & 8,35 \\
\hline $5-9$ & 17.186 & 8,16 & 16.297 & 7,80 & 33.483 & 7,98 \\
\hline $10-14$ & 16.967 & 8,05 & 16.434 & 7,87 & 33.401 & 7,96 \\
\hline $15-19$ & 19.138 & 9,08 & 19.607 & 9,39 & 38.745 & 9,23 \\
\hline $20-24$ & 23.523 & 11,16 & 22.332 & 10,69 & 45.855 & 10,93 \\
\hline $25-29$ & 20.141 & 9,56 & 17.917 & 8,58 & 38.058 & 9,07 \\
\hline $30-34$ & 16.483 & 7,82 & 15.930 & 7,63 & 32.413 & 7,72 \\
\hline $35-39$ & 15.442 & 7,33 & 15.579 & 7,46 & 31.021 & 7,39 \\
\hline $40-44$ & 15.080 & 7,16 & 15.393 & 7,37 & 30.473 & 7,26 \\
\hline $45-49$ & 14.047 & 6,67 & 14.258 & 6,83 & 28.305 & 6,75 \\
\hline $50-54$ & 11.604 & 5,51 & 11.425 & 5,47 & 23.029 & 5,49 \\
\hline $55-59$ & 9.318 & 4,42 & 9.42 & 4,51 & 18.738 & 4,47 \\
\hline $60-64$ & 6.222 & 2,95 & 6.445 & 3,09 & 12.667 & 3,02 \\
\hline $65-69$ & 3.617 & 1,72 & 4.157 & 1,99 & 7.774 & 1,85 \\
\hline $70-74$ & 2.137 & 1,01 & 2.854 & 1,37 & 4.991 & 1,19 \\
\hline $75+$ & 1.932 & 0,92 & 3.657 & 1,75 & 5.589 & 1,33 \\
\hline Jumlah & $\begin{array}{c}210.70 \\
6\end{array}$ & 100 & 208.890 & 100 & $\begin{array}{c}419.59 \\
6\end{array}$ & 100 \\
\hline
\end{tabular}

Sumber : BPS, Manado dalamangka 2014

Tabel 2 menunjukkan bahwa jumlah penduduk Kota Manado pada tahun 2014 sebesar 419.596 orang yang terdiri dari 210.706 orang laki-laki $(50,22 \%)$ dan 208.890 orang 
perempuan $(49,78 \%)$, dari data tersebut dapat dilihat bahwa penduduk laki-laki lebih banyak daripada penduduk perempuan. Besarnya jumlah penduduk di Kota Manado menyebabkan kepadatan penduduk menjadi cukup tinggi. Dengan luas wilayah 157,26 $\mathrm{Km} 2$, kepadatan penduduknya mencapai 2.668 jiwa/Km2.

\section{Pendidikan}

Pendidikan merupakan sarana untuk membentuk sumber daya manusia (SDM) yang ahli dan terampil serta produktif sehingga pada gilirannya dapat mempercepat peningkatan kesejahteraan masyarakat.

Berdasarkan data Badan Pusat Statistika (BPS) Kota Manado tahun 2014, jumlah penduduk menurut tingkat pendidikan dapat dilihat pada Tabel 3 berikut ini.
Tabel 3. Jumlah Penduduk Kota Manado Menurut Tingkat Pendidikan

\begin{tabular}{cccc}
\hline No & $\begin{array}{c}\text { Tingkat } \\
\text { Pendidikan }\end{array}$ & $\begin{array}{c}\text { Jumlah } \\
\text { (orang) }\end{array}$ & $\begin{array}{c}\text { Persentase } \\
(\%)\end{array}$ \\
\hline 1 & SD ke bawah & 58.586 & 18,39 \\
2 & SMP & 71.648 & 22,49 \\
3 & SMA ke atas & 188.397 & 59,12 \\
\hline & Jumlah & 318.631 & 100
\end{tabular}

Sumber : BPS, Manado dalam angka 2014

Tabel 3 menunjukkan bahwa tingkat pendidikan penduduk Kota Manado paling besar berada pada tingkat pendidikan SMA ke atas yaitu sebesar 188.397 orang $(59,12 \%)$, SMP yaitu sebesar 71.648 orang $(22,49 \%)$, dan SD ke bawah berjumlah 58.586 orang $(18,39 \%)$.

Tabel 4. Jumlah Penduduk Kota Manado Menurut Jenis Kelamin dan Lapangan Pekerjaan Utama

\begin{tabular}{|c|c|c|c|c|}
\hline \multirow[t]{2}{*}{ No } & \multirow[t]{2}{*}{ Uraian } & \multicolumn{3}{|c|}{ Jenis Kelamin } \\
\hline & & Laki-laki & Perempuan & Jumlah \\
\hline & (1) & $(2)$ & $(3)$ & (4) \\
\hline 1 & $\begin{array}{l}\text { Pertanian, Perkebunan, } \\
\text { Kehutanan, Perburuan } \\
\text { dan Perikanan }\end{array}$ & 6.833 & 613 & 7.446 \\
\hline 2 & $\begin{array}{l}\text { Pertambangan dan } \\
\text { Penggalian }\end{array}$ & 46 & - & 46 \\
\hline 3 & Industri & 4.288 & 2.443 & 6.731 \\
\hline 4 & Listrik, Gas Dan Air & 321 & - & 321 \\
\hline 5 & Konstruksi & 17.487 & - & 17.487 \\
\hline 6 & $\begin{array}{l}\text { Perdagangan, Rumah } \\
\text { Makan dan Jasa } \\
\text { Akomodasi }\end{array}$ & 28.973 & 28.528 & 57.501 \\
\hline 7 & $\begin{array}{l}\text { Transportasi, } \\
\text { Pergudangan dan } \\
\text { Komunikasi }\end{array}$ & 17.019 & 590 & 17.609 \\
\hline 8 & $\begin{array}{l}\text { Keuangan, Real Estate, } \\
\text { Persewaan dan Jasa } \\
\text { Perusahaan }\end{array}$ & 8.816 & 4.280 & 13.096 \\
\hline 9 & $\begin{array}{l}\text { Jasa Kemasyarakatan, } \\
\text { Sosial dan Perorangan }\end{array}$ & 28.551 & 25.639 & 54.190 \\
\hline
\end{tabular}

Sumber : BPS, Manado dalam angka 2014 


\section{Mata Pencaharian}

Berdasarkan data Badan Pusat Statistika Kota Manado tahun 2014, jumlah penduduk Kota Manado menurut mata pencaharian atau menurut lapangan pekerjaan utama terlihat pada Tabel 4 berikut ini.

Dari Tabel 4 dapat dilihat bahwa jumlah pekerjaan penduduk yang terbesar adalah pada sektor Perdagangan, Rumah Makan dan Jasa Akomodasi sebesar 57.501 orang (33\%), diikuti oleh sektor Jasa Kemasyarakatan, Sosial dan Perorangan sebesar 54.190 orang (31\%), dan sektor Transportasi, Pergudangan dan Komunikasi sebesar 17.609 orang (10\%).

\section{Sarana dan Prasarana}

Sarana dan prasarana sangat mempengaruhi perkembangan dan kemajuan masyarakat. Semakin baik sarana dan prasarana akan mempercepat laju pembangunan. Sarana dan prasarana di Kota Manado dapat dilihat pada Tabel 5 berikut ini.

Sarana pendidikan di Kota Manado sangat lengkap mulai dari Taman Kanak-kanak (TK) berjumlah 141 unit, Sekolah Dasar (SD) berjumlah 270 unit, Sekolah Menengah Pertama (SMP) berjumlah 94 unit, Sekolah Menengah Atas (SMA) berjumlah 84 unit, hingga ke Perguruan Tinggi berjumlah 33 unit dengan berbagai tingkat strata. Status sekolah pun beragam mulai dari negeri, swasta maupun sekolah madrasah yang tersebar di setiap sudut dan pelosok Kota Manado dengan kualitas yang beragam.

Tabel 5. Sarana dan Prasarana di Kota Manado

\begin{tabular}{|c|c|c|}
\hline No. & Sarana dan Prasarana & Jumlah (unit) \\
\hline \multirow[t]{6}{*}{1} & Sekolah & \\
\hline & a. TK & 141 \\
\hline & b. SD & 270 \\
\hline & c. SMP & 94 \\
\hline & d. SMA & 84 \\
\hline & e. Perguruan Tinggi & 33 \\
\hline \multirow[t]{6}{*}{2} & Kesehatan & \\
\hline & a. Puskesmas & 15 \\
\hline & b. Klinik & 18 \\
\hline & c. Posyandu & 323 \\
\hline & d. Rumah Bersalin & 2 \\
\hline & e. Rumah Sakit & 9 \\
\hline \multirow[t]{6}{*}{3} & Tempat Ibadah & \\
\hline & a. Gereja & 544 \\
\hline & b. Masjid & 187 \\
\hline & c. Musholla & 29 \\
\hline & d. Pura & 3 \\
\hline & e. Vihara & 18 \\
\hline \multirow[t]{5}{*}{4} & Transportasi & \\
\hline & a. Jalan baik & $35.442 \mathrm{~km}$ \\
\hline & b. Jalan sedang & $59.474 \mathrm{~km}$ \\
\hline & c. Jalan rusak & $81.102 \mathrm{~km}$ \\
\hline & e. Jalan rusak berat & $48.661 \mathrm{~km}$ \\
\hline \multirow[t]{3}{*}{5} & Pasar & \\
\hline & a. Pasar tradisional & 6 \\
\hline & b. Pasar modern & 39 \\
\hline
\end{tabular}

Sumber : BPS, Manado dalam angka 2014 
Sarana kesehatan yang ada di Kota Manado yaitu puskesmas 15 unit, klinik kesehatan 18 unit, posyandu 323 unit, rumah bersalin 2 unit, rumah sakit 9 unit.

Sarana peribadatan yang ada di Kota Manado yaitu gereja 544 unit, masjid 187 unit, musholla 29 unit, pura 3 unit, dan vihara 18 unit.

Sarana transportasi sangat lengkap di dalam kota, angkutan kota sangat banyak ke segala penjuru Kota Manado. Panjang jalan Kota Manado $540.680 \mathrm{~km}$. Jalan yang dalam kondisi baik sepanjang $35.442 \mathrm{~km}$, jalan dalam kondisi sedang $59.474 \mathrm{~km}$, jalan dalam kondisi rusak sepanjang $81.102 \mathrm{~km}$, dan jalan dalam kondisi rusak berat sepanjang $48.661 \mathrm{~km}$.

Terdapat pasar tradisional maupun pasar modern di Kota Manado. Masyarakat dengan mudah memilih ingin berbelanja di pasar tradisional dan pasar modern. Ada 6 unit pasar tradisional dan 39 unit pasar modern yang tersebar di setiap kecamatan dengan keunggulan dan kelengkapan masing-masing pasar yang berbeda-beda. Pasar tradisional umumnya buka pada pagi hari, sedangkan pasar modern buka dari pagi hingga malam hari.Dalam penelitian ini yang menjadi sampel yaitu pasar tradisional Pinasungkulan Karombasan dan pasar modern Freshmart Swalayan Bahu.

\section{Deskripsi Responden}

Responden dalam penelitian ini terdiri dari masyarakat atau konsumen komoditi pertanian yang ada di Kota Manado. Selanjutnya responden akan didistribusi berdasarkan kelompok umur, tingkat pendidikan, jenis pekerjaan, dan pendapatan .Jumlah responden yang diteliti pada penelitian ini adalah sebanyak 60 orang.

\section{Distribusi Responden Berdasarkan Kelompok Umur}

Dalam penelitian ini, umur responden adalah 20 sampai 65 tahun. Umur responden yang berada pada kelompok umur 20-34 tahun dengan jumlah 27 orang (45\%), jumlah responden yang berada pada kelompok umur 35-50 tahun dengan jumlah 26 orang (43\%), dan jumlah responden yang berada pada kelompok umur 51-65 tahun dengan jumlah 7 orang (12\%). Untuk lebih jelasnya dapat dilihat pada Tabel 6.

Tabel 6. Jumlah Responden Menurut Kelompok Umur

\begin{tabular}{cccc}
\hline No & $\begin{array}{c}\text { Kelompok } \\
\text { Umur } \\
\text { (Tahun) }\end{array}$ & $\begin{array}{c}\text { Jumlah } \\
\text { Responden }\end{array}$ & $\begin{array}{c}\text { Persentase } \\
(\%)\end{array}$ \\
\hline 1 & $20-34$ & 27 & 45 \\
2 & $35-50$ & 26 & 43 \\
3 & $51-65$ & 7 & 12 \\
\hline & Jumlah & 60 & 100 \\
\hline
\end{tabular}

Sumber : Diolah dari Data Primer, 2015

\section{Distribusi Responden Berdasarkan Tingkat Pendidikan}

Dilihat dari tingkat pendidikan terakhir responden, jumlah responden didominasi oleh responden yang berpendidikan SMA yaitu sebesar 51,6\% atau sebanyak 31 orang, urutan kedua terbanyak adalah responden berpendidikan sarjana yaitu sebesar $36,7 \%$ atau sebanyak 22 orang, kemudian Diploma sebanyak sebesar 5\% atau sebanyak 3 orang, kemudian responden dengan pendidikan SMP sebesar $5 \%$ juga atau sebanyak 3 orang, dan yang terakhir adalah responden dengan tingkat pendidikan SD sebesar 1,7\% atau sebanyak 1 orang. Kondisi ini mendukung penelitian karena dengan dominannya responden yang berpendidikan maka proses pengambilan data di lapangan dapat dilakukan dengan baik. Untuk lebih jelasnya distribusi responden menurut pendidikan dapat dilihat pada Tabel 7 berikut ini.

\section{Tabel 7. Jumlah Responden Menurut} Tingkat Pendidikan

\begin{tabular}{|c|c|c|c|}
\hline $\mathrm{N}$ & $\begin{array}{c}\text { Pendidikan } \\
\text { Terakhir }\end{array}$ & $\begin{array}{c}\text { Jumlah } \\
\text { Responden }\end{array}$ & $\begin{array}{c}\text { Persentase } \\
(\%)\end{array}$ \\
\hline 1 & SD/Sederajat & 1 & 1,7 \\
\hline 2 & SMP/Sederajat & 3 & 5 \\
\hline 3 & SMA/Sederajat & 31 & 51,6 \\
\hline 4 & Diploma & 3 & 5 \\
\hline 5 & Sarjana & 22 & 36,7 \\
\hline & Jumlah & 60 & 100 \\
\hline
\end{tabular}

Sumber : Diolah dari Data Primer, 2015

Pada Tabel 7 terlihat bahwa responden berdasarkan tingkat pendidikan dengan urutan 
teratas yaitu responden dari tingkat SMA dan yang terbawah adalah tingkat pendidikan SD.

\section{Distribusi Responden Berdasarkan Pendapatan}

Jika dilihat dari jumlah pendapatan per bulan, maka responden yang diteliti didominasi oleh mereka yang berpenghasilan antara $\mathrm{Rp} 2,5$ juta- 5 juta per bulan yaitu sebesar $48 \%$ atau sebanyak 29 orang. Diikuti oleh responden yang berpenghasilan kurang dari $\mathrm{Rp} \mathrm{2,5}$ juta per bulan yaitu sebesar $40 \%$ atau sebanyak 24 orang. Sedangkan yang paling sedikit porsinya dalam penelitian ini adalah responden yang berpendapatan lebih dari 5 juta- 10 juta per bulan sebesar $12 \%$ atau sebanyak 7 orang. Untuk lebih jelasnya dapat dilihat pada Tabel 8.

Tabel 8. Jumlah Responden Menurut Tingkat Pendapatan

\begin{tabular}{cccc}
\hline No & $\begin{array}{c}\text { Pendapatan } \\
\text { Per/bulan }\end{array}$ & $\begin{array}{c}\text { Jumlah } \\
\text { Responden }\end{array}$ & $\begin{array}{c}\text { Persent } \\
\text { ase (\%) }\end{array}$ \\
\hline 1 & < Rp. 2.500.000 & 24 & 40 \\
2 & $\begin{array}{c}\text { Rp. 2.500.000- } \\
\text { Rp. 5.000.000 }\end{array}$ & 29 & 48 \\
3 & $\begin{array}{c}\text { Rp. 5.000.000- } \\
\text { Rp. 10.000.000 }\end{array}$ & 7 & 12 \\
\hline & Jumlah & 30 & 100 \\
\hline
\end{tabular}

Sumber : Diolah dari Data Primer, 2015

\section{Hasil Analisis Faktor-faktor yang Menentukan Pilihan Konsumen Komoditi Pertanian Untuk Berbelanja di Pasar Tradisional atau Pasar Modern.}

Berdasarkan uji yang telah dilakukan untuk menganalisis seberapa besar pengaruh variabel independen yaitu umur (X1), pendidikan (X2), pendapatan (X3), lokasi (X4), produk (X5), harga (X6), atmosfir dalam gerai (X7), pelayanan (X8), kenyamanan (X9), gengsi (X10) terhadap variabel dependen yaitu frekuensi peluang berbelanja ke pasar di kotaManado ( $\mathrm{Zi})$ dengan menggunakan persamaan yang ada pada bab III maka diperoleh hasil estimasi sebagai berikut :

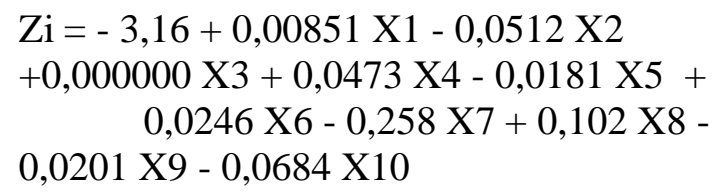

Secara keseluruhan bahwa variabel independen yaitu umur (X1), pendidikan (X2), pendapatan (X3), lokasi (X4), produk (X5), harga (X6), atmosfir dalam gerai (X7), pelayanan (X8), kenyamanan (X9), gengsi (X10) mempengaruhi keputusan konsumen komoditi pertanian dalam berbelanja di pasar tradisional dan pasar modern karena $\mathrm{P}(0,000)<$ $\mathrm{P}(0,05)$.

\section{Tabel 9. Hasil Analisis Regresi Faktor Penentu Pilihan Konsumen Komoditi Pertanian Terhadap Tempat Berbelanja di Pasar Tradisional dan Pasar Modern di Kota Manado}

\begin{tabular}{ccccc}
\hline Predictor & Coef & SE Coef & T & P \\
\hline Constant & $-3,1642$ & 0,9419 & $-3,36$ & 0,002 \\
\hline X1 & 0,008506 & 0,00753 & 1,13 & 0,264 \\
& \multicolumn{5}{c}{0} \\
\hline X2 & $-0,05122$ & 0,07949 & $-0,64$ & 0,522 \\
\hline X3 & 0,000000 & 0,00000 & 1,25 & 0,219 \\
\multicolumn{1}{c}{07} & 006 \\
\hline X4 & 0,04729 & 0,03777 & 1,25 & 0,217 \\
\hline X5 & $-0,01812$ & 0,05838 & $-0,31$ & 0,758 \\
\hline X6 & 0,02464 & 0,03900 & 0,63 & 0,531 \\
\hline X7 & $-0,2577$ & 0,1086 & $-2,37$ & 0,022 \\
\hline X8 & 0,10193 & 0,07174 & 1,42 & 0,162 \\
\hline X9 & $-0,02011$ & 0,04156 & $-0,48$ & 0,631 \\
\hline X10 & $-0,06838$ & 0,09404 & $-0,73$ & 0,471 \\
\hline S = 0,4820 & R-Sq $=48,9 \%$ & R-Sq(adj) $=38,4 \%$
\end{tabular}

Tabel 9 untuk menjelaskan tentang signifikansi pengaruh variabel bebas terhadap variabel tidak bebas secara parsial. Hasil analisis menunjukkan bahwa besarnya variabel peluang konsumen dalam memilih tempat berbelanja yang dapat dijelaskan oleh variabel ternyata hanya sebesar $38,4 \%$. Ini artinya $61,6 \%$ dijelaskan oleh variabel-variabel lain yang tidak dimasukkan dalam model.

Hasil menunjukkan bahwa terdapat dua variabel yaituatmosfir dalam gerai $(\mathrm{P}<0,05)$ dan pelayanan $(\mathrm{P}<0,20)$, artinya kedua variabel tersebut menentukan pilihan konsumen dalam memilih tempat berbelanja. Sedangkan 
variabel umur, pendidikan, pendapatan, lokasi, produk, harga, kenyamanan, dan gengsi memiliki nilai $\mathrm{P}>0,20$, artinya variabel tersebut tidak menentukan pilihan konsumen dalam memilih tempat berbelanja. Berdasarkan pada hasil tersebut, signifikansi pengaruh dari masing-masing variabel dapat dijelaskan sebagai berikut :

\section{Umur}

Hasil analisis menunjukkan bahwa
umur tidak signifikan terhadap tingkat keputusan konsumen komoditi pertanian dalam berbelanja di pasar tradisional dan pasar modern di kota Manado karena $\mathrm{P}>0,20$. Hal ini disebabkan karena umur tidak menjamin seseorang untuk tidak berbelanja ke pasar, baik pasar tradisional maupun pasar modern. Artinya baik orangtua maupun anak muda sama-sama butuh untuk berbelanja ke pasar dan tidak berbatas pada usia seseorang. Sebab yang menjadi pertimbangan bagi mereka yaitu adalah bagi seseorang, siapapun itu pasti memiliki kebutuhan untuk berbelanja di pasar tidak melihat usia berapapun mereka, karena walaupun yang berbelanja adalah kepala keluarga tetapi jika membawa serta anak mereka untuk ikut serta mengunjungi pasar, maka anak tersebut akan timbul permintaannya untuk suatu barang yang dia inginkan dalam pasar tersebut. Sehingga dalam penelitian ini variabel umur tidak berpengaruh terhadap kunjungan konsumen ke pasar tradisional dan pasar modern di Kota Manado.

\section{Tingkat Pendidikan}

Tingkat pendidikan formal yang dimiliki konsumen akan menunjukkan tingkat pengetahuan serta wawasan dalam mengambil keputusan. Hasil analisis menunjukkan bahwa pendidikan tidak signifikan terhadap tingkat keputusan konsumen komoditi pertanian dalam berbelanja di pasar tradisional dan pasar modern di Kota Manado karena $\mathrm{P}>0,20$. Konsumen yang memiliki tingkat pendidikan yang tinggi bukan berarti harus berbelanja di pasar modern.Konsumen yang memiliki tingkat pendidikan yang rendah juga tidak harus berbelanja di pasar tradisional, melainkan untuk produk tertentu mereka lebih memilih ke pasar tradisional maupun ke pasar modern disesuaikan dengan kebutuhan mereka.

\section{Tingkat Pendapatan}

Hasil analisis menunjukkan bahwa pendapatan tidak signifikan terhadap tingkat keputusan konsumen komoditi pertanian dalam berbelanja di pasar tradisional dan pasar modern di Kota Manado karena $\mathrm{P}>0,20$.

Tinggi rendahnya pendapatan konsumen tidak sepenuhnya menentukan kemana mereka berbelanja, untuk konsumen yang berpenghasilan rendah juga mau memutuskan untuk berbelanja di pasar modern untuk barangbarang tertentu.

\section{Lokasi}

Jauh dekatnya lokasi pasar juga terkadang menjadi pertimbangan penting bagi konsumen, ada yang berpendapat lebih baik ke pasar yang dekat dengan tempat tinggal, namun ada juga yang memilih tempat berbelanja itu bukan hanya karena faktor lokasi.

Hasil analisis menunjukkan bahwa lokasi tidak signifikan terhadap tingkat keputusan konsumen komoditi pertanian dalam berbelanja di pasar tradisional dan pasar modern di Kota Manado karena P > 0,20 .

\section{Produk}

Kelengkapan produk merupakan salah satu faktor penting bagi konsumen untuk berbelanja dalam memenuhi kebutuhannya, kualitas produk yang dijual pun akan menarik minat konsumen yang akan berbelanja. Hasil analisis menunjukkan bahwa produk tidak signifikan terhadap tingkat keputusan konsumen komoditi pertanian dalam berbelanja di pasar tradisional dan pasar modern di Kota Manado karena $\mathrm{P}>0,20$.

\section{Harga}

Faktor harga merupakan salah satu pertimbangan bagi konsumen dalam berbelanja, Sebagian besar konsumen paling suka dengan sistem tawar-menawar atau harga ditetapkan bersama di waktu membeli produk tersebut, bukan harga yang telah ditetapkan sebelumnya, Namun sebagian lagi lebih menyukai harga yang telah ditetapkan sebelumnya. Hasil analisis menunjukkan bahwa harga tidak signifikan terhadap tingkat keputusan konsumen 
komoditi pertanian dalam berbelanja di pasar tradisional dan pasar modern di Kota Manado karena $\mathrm{P}>0,20$.

\section{Atmosfir dalam gerai}

Atmosfer dalam gerai berperan penting dalam memikat pembeli, suasana yang baik dan penataan barang yang ditata dengan baik membuat nyaman mereka, dan mengingatkan mereka produk apa yang perlu dimiliki. Atmosfir dalam gerai menentukan secara signifikan terhadap pilihan tempat berbelanja dari konsumen komoditi pertanian. Tanda negatif menunjukkan bahwa semakin tinggi pemilihan konsumen terhadap atmosfir dalam gerai, maka semakin rendah peluangnya untuk memilih pasar tradisional sebagai tempat berbelanja atau dengan kata lain konsumen yang menginginkan atmosfir dalam gerai yang baik, lebih memilih pasar modern sebagai tempat berbelanja karena $\mathrm{P}<0,05$.

\section{Pelayanan}

Pelayanan merupakan sebuah aktifitas, manfaat atau kepuasan yang ditawarkan kepada konsumen, seperti pelayanan yang ramah dan sopan kepada konsumen dan juga pelayanan yang cepat dalam melayani konsumen. Pelayanan menentukan secara signifikan terhadap pilihan tempat berbelanja dari konsumen komoditi pertanian. Tanda positif menunjukkan bahwa semakin tinggi pemilihan konsumen terhadap pelayanan, maka semakin tinggi peluangnya untuk memilih pasar tradisional sebagai tempat berbelanja atau dengan kata lain konsumen yang menginginkan pelayanan yang baik, lebih memilih pasar tradisional sebagai tempat berbelanja karena $\mathrm{P}$ $<0,20$

\section{Kenyamanan}

Kenyamanan dalam berbelanja merupakan faktor yang dapat mempengaruhi konsumen dalam berbelanja seperti tempat yang bersih, luas dan aman. Hasil analisis menunjukkan bahwa kenyamanan tidak signifikan terhadap tingkat keputusan konsumen komoditi pertanian dalam berbelanja di pasar tradisional dan pasar modern di Kota Manado karena $\mathrm{P}>0,20$.

\section{Gengsi}

Hasil analisis menunjukkan bahwa gengsi tidak signifikan terhadap tingkat keputusan konsumen komoditi pertanian dalam berbelanja di pasar tradisional dan pasar modern di Kota Manado karena $\mathrm{P}>0,20$. Sebagian kecil dari konsumen yang berbelanja di pasar modern memiliki gengsi atau kebanggaan tersendiri ketika membeli atau menggunakan produk tertentu yang di beli di pasar modern, namun kebanyakan dari konsumen beranggapan bahwa gengsi itu tidak memberikan pengaruh apa-apa bagi mereka dalam berbelanja.

Koefisien determinasi (R-Sq) untuk mengetahui seberapa besar variasi perubahan variabel dependen ditentukan oleh perubahan variabel independen secara bersama-sama. Dari hasil pengolahan data menggunakan minitab yang terdapat pada Lampiran (Lampiran 1), menunjukkan $\mathrm{R}-\mathrm{Sq}=48,9 \%$. Ini dapat diartikan bahwa variabel bebas yaitu umur (X1), pendidikan (X2), pendapatan (X3), lokasi (X4), produk (X5), harga (X6), atmosfir dalam gerai (X7), pelayanan (X8), kenyamanan (X9), gengsi (X10) mampu menerangkan variasi variabel dependen sebesar 48,9\% dan terdapat sebanyak $51,1 \%$ ditentukan oleh faktor-faktor lain yang tidak masuk dalam variabel penjelas.

Berdasarkan hasil penelitian, maka dihasilkan 2 variabel bebas yang signifikan yaitu atmosfir dalam gerai dan pelayanan, sehingga model Logistik yang dibangun dalam penelitian ini adalah sebagai berikut:

$$
\begin{aligned}
P_{i}= & F\left(\beta_{0}+\beta_{1} X_{1 i}\right)=\frac{1}{1+e^{-Z_{i}}} \\
Z_{i}= & -2,03-0,351 \text { Atmosfir dalam gerai }+ \\
& 0,106 \text { Pelayanan } \\
P_{i}= & \frac{1}{1+e^{-(-2,03-0,351 \times 7+0,106 \times 8)}}
\end{aligned}
$$

Berdasarkan persamaan tersebut diatas, maka dapat dihitung probabilitas atau prediksi peluang konsumen komoditi pertanian memilih tempat berbelanja ke pasar tradisional atau modern.Besarnya peluang bagi konsumen komoditi pertanian untuk memilih tempat berbelanja, dilakukan dengan membandingkan kekuatan kedua variabel yang signifikan yaitu atmosfir dalam gerai dan pelayanan sebagai faktor penentu, terhadap peluang konsumen 
komoditi pertanian memilih tempat berbelanja ke pasar tradisional atau pasar modern.

Dengan persamaan diatas dapat diketahui bahwa semakin meningkat nilai $\mathrm{X} 7$ maka nilai $P_{i}$ akan menurun, artinya dari segi variabel atmosfir dalam gerai akan menentukan konsumen komoditi pertanian untuk memilih pergi berbelanja di pasar modern, sedangkan semakin meningkat nilai X8 maka nilai $\mathrm{P}_{\mathrm{i}}$ akan meningkat, artinya dari segi variabel pelayanan akan menentukan konsumen komoditi pertanian untuk memilih pergi berbelanja di pasar tradisional.

Hasil analisis regresi pada Lampiran 2 menunjukkan koefisien dugaan pada variabel $\mathrm{X} 7$ atau atmosfir dalam gerai adalah sebesar 0,35056 , artinya variabel tersebut bernilai negatif yang berarti semakin baik atmosfir dalam gerai, maka menentukan konsumen komoditi pertanian untuk memilih pergi berbelanja di pasar modern, sedangkan variabel $\mathrm{X} 8$ atau pelayanan adalah sebesar 0,10589 , artinya variabel tersebut bernilai positif yang berarti semakin baik pelayanan, maka menentukan konsumen komoditi pertanian untuk memilih pergi berbelanja di pasar tradisional

\section{KESIMPULAN DAN SARAN}

\section{Kesimpulan}

Variabel umur, tingkat pendidikan, penghasilan, lokasi, produk, harga, kenyamanan, dan gengsi bukan merupakan faktor penentu pilihan konsumen komoditi pertanian dalam memilih tempat berbelanja, sedangkan atmosfir dalam gerai dan pelayanan merupakan faktor penentu pilihan konsumen komoditi pertanian dalam memilih tempat berbelanja. Konsumen yang menginginkan atmosfer gerai yang tinggi, lebih memilih pergi berbelanja ke pasar modern, sedangkan konsumen yang menginginkan pelayanan yang baik, lebih memilih berbelanja ke pasar tradisional.

\section{Saran}

Bagi Pemerintah Kota Manado, PD Pasar sebaiknya memaksimalkan perhatiannya terhadap sarana dan prasarana di pasar tradisional, juga Pemko Manado bisa memberikan penyuluhan bagi pedagangpedagang di pasar agar pedagang-pedagang lebih memperhatikan kebersihan pasar, lebih ramah dan lebih cekatan dalam melayani konsumen dan agar pedagang lebih baik dalam menyusun barang-barang dagangannya, serta menjual barang-barang yang lebih berkualitas. Perlu ada penelitian tentang variabel lain yang menentukan

\section{DAFTAR PUSTAKA}

Arif M.N., 2011. Analisis Faktor-faktor Yang Mempengaruhi Perilaku Konsumen Dalam Pembelian Produk Sophie Martin Pada BC. Ivrina Katili. Universitas Hasanuddin Makassar.

Arsyad L., 2000. Ekonomi Manajerial. Yogyakarta: BPFE.

Fadhilah A.N., 2011. Dampak Minimarket Terhadap Pasar Tradisional (Studi Kasus di Ngaliyan). Skripsi Institut Agama Islam Negeri Walisongo Semarang.

Gaspersz V., 1992. Teknik Analisis Dalam Penelitian Percobaan. TARSITO. Bandung.

Ismail M., 2012. Strategi Pemasaran Untuk Membangun Citra dan Loyalitas Merek.IPB Press. Bogor

Jendi R., 2013. Analisis Faktor-faktor Yang Mempengaruhi Perilaku Konsumen Berbelanja di Supermarket di Kota Padang.Skripsi Universitas Negeri Padang.

Kasmir, Jakfar., 2004. Studi Kelayakan Bisnis. Jakarta: Kencana.

Karo Karo B., 2009. Analisis Pasar Tenaga Kerja di Sumatera Utara.Tesis Universitas Sumatera Utara. 
Malano H., 2011. Selamatkan Pasar Tradisional: Potret Ekonomi Rakyat Kecil. PT Gramedia Pustaka Utama. Jakarta.

Masitoh., 2013. Upaya Menjaga Eksistensi Pasar Tradisional: Studi Revitalisasi Pasar Piyungan Bantul. Jurnal PMI Vol. X. No. 2.

Masni Y., 2014. Analisis Preferensi Konsumen Dalam Berbelanja di Pasar Tradisional dan Pasar Modern di Kota Makassar.Skripsi Universitas Hasanuddin Makasar.

Oentoro D., 2012.Manajemen Pemasaran Modern. LaksBang PRESSindo. Yogyakarta.

Purba S.A., 2009. Faktor-faktor Yang Mempengaruhi Keputusan Konsumen Dalam Berbelanja di Pasar Tradisional dan Pasar Modern (Studi kasus : Konsumen Pasar Tradisional Sei Sikambing dan Brastagi Swalayan, Kota Medan). Skripsi Universitas Sumatera Utara.

Radhi F., 2008. Kebijakan Ekonomi Pro Rakyat.Republika. Jakarta.

Rengkung L.R., 1997. Efektivitas Pengelolaan Dana IDT Serta Faktor-Faktor Yang Mempengaruhinya (Suatu Studi pada Beberapa Kelompok Masyarakat/POKMAS di Kabupaten Minahasa). Tesis Universitas Indonesia.
Sangadji, Sopiah., 2013. Perilaku Konsumen Pendekatan Praktis Disertai Himpunan Jurnal Penelitian. Yogyakarta: ANDI.

Siregar R.S.N., 2011. Analisis Perbandingan Faktor-Faktor Yang Mempengaruhi Keputusan Pembelian di Pasar Modern Carrefour Citra Garden Padang Bulan Medan Dengan Pasar Tradisional Pajak Sore Padang Bulan Medan. Skripsi Universitas Sumatera Utara.

Subagyo, J. P., 2006. Metode Penelitian. PT. Rineka Cipta, Jakarta.

Swastha B, Handoko T., 2000. Manajemen Pemasaran : Analisis Perilaku Konsumen". Yogyakarta : BPFE.

Tjiptono F., 2014. Pemasaran Jasa - Prinsip, Penerapan, dan Penelitian. Yogyakarta: ANDI. , 2014.Manado Dalam Angka.Badan Pusat Statistik Kota Manado. 